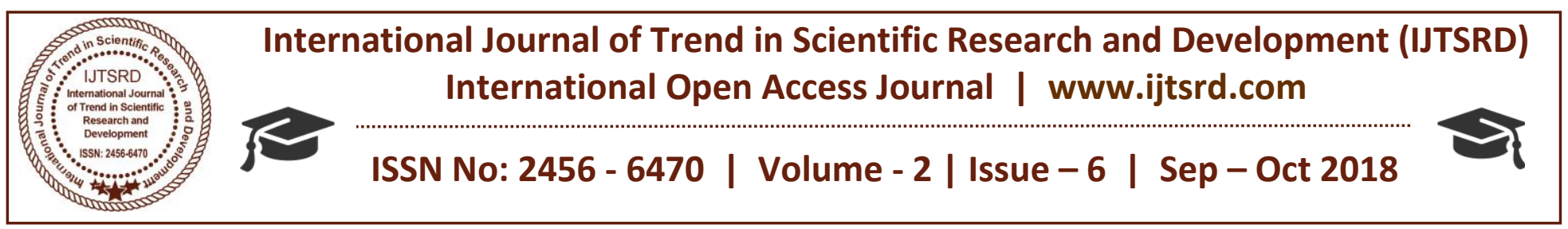

\title{
Hospitality Management: Innovation and Challenges
}

\author{
Karthik \\ Visiting Faculty, Department of Commerce, Udupi, Karnataka, India
}

\begin{abstract}
This paper aims to provide various insights on innovative practices followed by hospitality industry representing samples of hotels and restaurants operating in Manipal and Udupi, in Karnataka, whereby the industry is transforming itself to the new technological application and digital marketing aspects in day to day operation, revenue management, capacity utilization. The research focuses on the traditional hotels and lodging equipping to the new practices in recent years with different web portal and other marketing aggregators.
\end{abstract}

The paper has facts and from the existing literature and other reports. Primary data collection involving face to face conversations with the Managers of the hotels and the restaurant through questionnaires and in depth interview method. Secondary data includes webpages of online travel aggregators and hospitality firms.

Some of the key emerging areas are role of ecommerce, competitive advantage, leverage of technology and change management, operational efficiency. The paper also suggests that it is important to understand how innovations are being managed across different areas of operations in hospitality industry and focuses on aspects of hurdles and barriers faced by the managers towards implementation of innovative ideas and processes.

Keyword: New service design, technological adoption, service operational efficiency, capacity utilization, barriers and complexity faced in adopting new technology, revenue management

Practical Implications: Innovation is the order of the day, Udupi district has made a prominent name in the hotel industry all over the world in respect of restaurants and south Indian cuisines and also as a

temple place and as an education hub. This paper is of interest to the hoteliers and management students with reference to innovative practices undertaken by hotels and lodging in this location which is categorized into tier 3 cities by adopting technological aspects in day to day operations and also collaboration with online and other marketing aggregators for their revenue management and capacity utilization and over all operational efficiency in general.

Originality/Value: This paper has been written after extensive literature references in the related area, further all the papers in this theme issue were written after several rounds of interaction with practitioners to include real- time, relevant and contemporary data.

\section{INTRODUCTION}

Service sector plays an important role in the development of economy and has under seen a tremendous change in the recent years mainly after the advent of technological innovation and information technology applications in terms of commercial transactions with focus to service industry. For example: Hotel industry in the Indian market has undergone change in their revenue management and operational aspects by collaborating itself with online booking web portals and a new revenue model of sharing a part of their property booking with these online travel agencies. With a consistently growing middle class and increasing disposable income, the tourism and hospitality sector is having a healthy growth and accounts for 7.5 per cent of the country's GDP. According to a report by KPMG, the hospitality sector in India is expected to grow at 16.1 per cent CAGR to reach Rs.2, 796.9 thousand crore in 2022. The sector attracts the most FDI (Foreign Direct Investment) inflow and is the most important net foreign exchange earners for the country. The number of Foreign Tourist Arrivals (FTAs) increased 10.8 per centyear-on-year to 3.88 
million. The travel \& tourism sector in India took into account 8 per cent of the total employment opportunities generated in the country in 2017, and provided employment to around 41.6 million people during the same year. The number is expected to rise by 2 per cent annum to 52.3 million jobs by 2028. International hotel chains are increasing their presence in the country, as it will register for around 47 per cent share in the Tourism \& Hospitality sector of India by $2020 \& 50$ per cent by 2022 .

\section{Defining innovation in the hospitality}

"Business has only two basic functions-marketing and innovation."- Peter Drucker

The hospitality industry is a vast group of fields within the service industry that includes lodging, event planning, theme parks, transportation, cruise line, and additional fields within the tourism industry. The term "hospitality management" refers to a range of occupations and professional practices associated with the administration of hotels, resorts and other lodging. Services carry a unique feature of intangibility and a quality of simultaneous production and consumption (Parasuraman, Zeithaml and Berry 1985)

The consumer behavior in the tourism and hospitality industry is a complicated task to analyze (Siakalli, Masouras, Papademetriou, 2017) Tourism industries in the present day has been revolutionized with innovative technologies and business models (Bilgihan\&Nejad, 2015) Examples of such innovations are phone-as-key-cards, mobile selfcheck-in, mobile booking, self-service check-in kiosks, lobby media panels, scheduling of the hotel rooms through online mode, payment through electronic wallet. There is shift from traditional marketing strategy and integration is being done with traditional4P's (Product, Place, Price, Promotion) and the Customer Relations (C) with e-marketing strategy( Siakalli et al., 2017) .This analysis was conducted through cross sectional survey to understand to a great extent hotel industries are following traditional marketing approaches and they are moving ahead towards exploring new possibilities through internet marketing strategies along with $4 \mathrm{ps}$ of marketing Product, Place, Price, Promotion) and the Customer Relations is used as an e-marketing strategy (Dr. Siakalli et al., 2017)
The present day business is undergoing changes every moment or a day, Innovation has become order of the day for sustenance in the market and long term survival of the business enterprises in the market is dependent on competitive factors and innovative practices of these firms to sustain in the competitive markets. These factors are applicable to all sectors of the economy. The present research is on the service industry with specific reference to hospitality industry. Service industry is vast in nature one among them is hospitality industry, Competitive practices and technological advancements are factors of innovation which decides the sustenance of hospitality industries in the market. Due to strong competition, numerous technological advancements and changes in consumers taste, firms survival depends on their capacity to develop or adopt innovations. There is a need for integrated approach with respect to the innovations in the service industry from each level of the service enterprises (Bilgihan\&Nejad, 2015)

Increase in supply of hotel chains is an important strategic factor which the other players in hotel industry has to create differentiated products and deliberate and consistent efforts to innovate the service strategies has to be planned to gain competitive edge(Sanjeev.M.\&Bandyopadhyay,2016) Service level innovation includes radical innovation and incremental innovation,

\section{Radical Innovations}

Major Innovation: new service for markets as yet defined(information and computer based technology

Start-up Business: new service for existing market At present New Services for the Market Served: new services to customers of an Organization.

\section{Incremental Innovations}

$>$ Service Line Extensions: addition of existing service line (e.g. new menu items)

$>$ Service Improvements: replace in features of currently offered service

$>$ Style Changes: modest visible changes in appearances

\section{About Udupi}

Udupi district, which is popularly known as temple town and education hub due to presence of Manipal University in this district. This place is blessed with a fairly $100 \mathrm{~km}$ long beautiful coastline and tourists visit this place mainly on pilgrimage and other tourist 
destinations and mainly for the purpose of education and related activities

Similarly hotels and restaurants situated in tier 3 cities like Udupi district of Karnataka has adopted innovative measures for the capacity utilization, scheduling, revenue management and operational efficiency and having a competitive edge over their rival firms by differentiating their services strategy and gaining operational efficiency by leveraging technology

\section{Recent Startups and Digital marketing of tourism sector}

All in all, hotels in India and around the world should acknowledge the power of social media and digital marketing, which are investing in it liberally, and are tapping into its hidden revenue sources. Looking ahead, connecting with customers on the move through mobile marketing is the next great challenge for hoteliers Development of information technology and innovation in the area of travel and leisure industry has led to many startups to grow in the Indian market and has made marketing of travel services easily accessible through digital marketing .For example. Indian travel industry has seen recent development of online travel marketing portals offering the best prices on flights, hotels and holiday packages across India and the world and also for planning and buying a holiday or a business trip easy and convenient. Some of the web pages in India are travel guru, yatra.com, tripadvisor.com. Hotelscombined.In Trivago.in. Hotels-scanner.com., in.hotels.com. makemytrip.com goibibo.com. The franchising model of hotel chains has made their presence in the hospitality market where there is model of revenue sharing basis with the owner of the hotel property .It has been a great significance to the hotel industry owners as there is effective revenue management and efficient scheduling and management of rooms.

\section{Digital Marketing}

The role of digital marketing and e-commerce is of great significance to the hospitality firms dealing with leisure and holidays. Tourism sector has gained competitive advantage through online and ECommerce platforms, as tourism service pattern has evolved a change in their offerings effective marketing strategies are being adopted by hospitality industries for effective customer relationship management and retention and careful tracking of reviews posted by the consumers are performed by the managers and hotel industry practitioners (Miguéns,Baggio,Costa,2008) The future growth of hospitality industry with reference to the sales and marketing transactions of the hotels is depended on the digital marketing strategies. (mahendru ,2015).

\section{LITERATURE REVIEW}

Kavoura and Stavrianea, (2015). Innovation in various spheres of the hospitality industry in this research included application of information technology to the areas of revenue management, marketing and sales, capacity utilization and gaining over all operational efficiency and optimum leverage of technology and ecommerce. Social networking platforms are attaining a great prominence in hospitality marketing there is a innovative concept of paid advertisements which is an innovative marketing strategy among the hospitality industry

Miguéns et al., (2008).Social media and consumer generated content are playing an important role in promoting tourism industry and it is one form of innovational practices where hospitality companies are registering and following those web pages. The study was to analyze how the users collaborate to image a destination in the webpage of trip advisor.com with the sample of all the hotels In Tripadvisor.Com for the city of Lisbon.

Froehle,(2006) Customer service operations has been subjected to rapid technological changes in service industry having a direct implication on consumer satisfaction

Miguéns et al., (2008) There is change in consumption pattern of tourism services and the assistance of online web portals are a great significance.

Froehle (2006) Customer service representatives and the characteristics exhibited by them along with the technology mediated environments have direct influence on consumer satisfaction, this research was carried out through exploratory research methodology to get an understanding among the managers of hotel whether managers should match this exploratory research examines the should managers attempt to match CSRs, based on their customer-observable characteristics, to particular communication media depending on its richness

Froehle, Roth, Chase ,Voss ,(2000) Technological developments in the area of service 
industry coupled with globalization is making service offerings obsolete, hence the hospitality enterprises are developing their new service development strategies through internet technologies

$>$ Ivkov , Blesic, Simat, Demirović, Bozic, Stefanovic,(2016) Technological advancements are reducing the dependence on labor and it is one of an innovation in hospitality industry

$>$ Rajasekaran R \& Sudarshan In the present era of information and communication technology (ICT), and its vast wide applications has been a great significance to a hospitality industry which has led them to explore various opportunities for offering their services through various attractive offers and most of the enterprises have adopted online marketing strategies, as a result $\mathrm{E}$ Commerce has been the instrumental factor behind the success of tourism and hospitality industry in this competitive era. The present study was conducted through a detailed questionnaire and suitable statistical tools were applied for analysis with the population sample of tour operators and hospitality practitioners where analysis revealed that online travel market and information technological application has enabled consumers for deciding on their purchases and travel packages by comparing a lot of information on destinations, hotels, facilities, price and tariff

$>$ Miguéns et al., (2008) Change in trend of booking through online modes and development of online travel aggregators has enabled a new competitive business models for hospitality enterprises

$>$ Froehle et al, (2000). Application of information technology facilitates new conceptual development of services which is preliminary evidence for overall innovation in the hospitality industry.

$>$ Innovations include online reservation systems and application of e-commerce platforms by the hospitality enterprises, Competency of manager and employees are having effect on innovations and service quality influences customer loyalty and retention. Innovative measures of the hospitality firms decide their survival in competitive market(Ivkov et.al,2016)

Mahendru, (2015) The opportunity of hotel industry marketing towards consumers via the internet became tangible and indeed, vital to growth as there is a change in the consumers perception towards hotels and restaurants potential and prospective consumers for the leisure industry prefer internet and websites as a trustworthy source for booking.

$>$ Sanjeev M \& Bandyopadhyay. (2016) Innovation works in separate or it is found effective when synchronized with other strategic initiatives of service enterprises and there is a factor of barrier among the managers in the course of adoption of innovative practices.

\section{Research gap}

While most of the researchers who researched on incremental innovation in hospitality businesses analyzed on various incremental innovation in restaurant industry and E-commerce and its relevance to hospitality industry in general. However, this paper tries to specifically provide an insight on how radical innovations with latest technological interventions with information and internet technology and new startups in the hospitality area serving the consumer needs.

\section{OBJECTIVES OF THE STUDY}

1. To analyze the innovative practices of operations with reference to the hospitality industry

2. To get an understanding on new service development strategies of the hotels and restaurant in this location.

3. To analyze the success rates of this hospitality enterprises with these innovative practices.

\section{4 DATA BASE AND METHODOLOGY}

As per the research Udupi district comprises around 50 -60 lodging out of which around 10 are working under star category. The questionnaires were distributed amongst the managers and also in depth interviews were taken. The sample included 60 hotels of all categories non classified and 2 and 3 stars, where in each hotel the manager was requested to complete the survey. The questionnaire was written in English and it has been developed after extensive literature review. The analysis has been tabulated and presented in cross tabulation formats representing comparison between different variables and the managers were asked to rank the most important areas of innovation by allocating the points ( $1=$ least important, 5=most important)a and so on and the same has been represented through Freidman's test analysis. 
V. CONCEPTUAL FRAMEWORK Dimensions and Factors of Innovation

Services marketing especially the hotel and restaurant marketing is comprised with new strategy of digital marketing for its future growth within the industry(Mahendru,2015) Bookings of hotels and destinations are characterized by rating of their property in the online platforms( Miguens et al., 2008).Innovation in hospitality enterprises are the reasons of competitive practices adopted by the hospitality firms by renewing and revitalizing service strategy as a result there is a consistent efforts among these firms to gain competitive advantage over the others. Innovations are addressed in every corner of the operation in the enterprises, an in depth face to face interview with the practitioners revealed that technological advancement is one of the factors concerned with innovation and the current-generation traveler is more inclined toward internet-based reservation systems where social media and other networking sites are playing an important role. Hence there is extensive revival on service offerings and incremental innovations are in process(Gunjan,2016).Internet is exploring a new territory in services and distribution, this exploratory research was to assess development of information technology and its implication on new service development and strategies(Froehle et al.,2000).The vast areas of application of digital technologies suggests that hotel industry practitioners should extend their thinking beyond internet and explore all possibilities of operating business electronically(Mahendru,2015)

Service level innovation included radical innovation and incremental innovation in the research Service enterprises constitute and contribute large percentage of the economy of every industrialized country. Despite the development of the service sector in the economy, academic research in this area has not been given a prominence. The relative lack of attention given to services provides competition and innovative research ideas to those students who pursue its study. Services are characterized by unique attributes that are strongly different from manufacturing sector. Consequently, specialized and different managerial techniques are employed in services than that are employed in many manufacturing firms, and knowledge and experience gained from studying manufacturing settings does not always transfer to services (metters,2012).Managers and practitioners of hotel industries become an important deciding factor for adoption of innovative practices (Sanjeev M \&Bandyopadhyay,2016)

There is an incremental technological innovations which has changed the way of service operations of restaurant business handle in each area of process of the industry (Mavale\&Rautela, 2016)

Service industry in order to equip with the current trends in market must exploit suitable and beneficial technological innovation (Mavale \& Rautela, 2016) Service enterprises which don't adopt technology innovation are likely to perish in the market (Mavale \& Rautela, 2016) In day to day operations did innovation work with integrated approach or isolated approach or through a strategic initiatives, this research aimed at studying and presenting facts and trends relating to innovations in the hospitality industry through extensive literature review and in depth interviews with the practitioners (Sanjeev M \&Bandyopadhyay,2016)

As discussed above hotels and restaurants has under seen innovative changes in the decade adopting various Information technology applications in various aspects of day to day operation.

The analysis showed that hotels and lodging had a tie up with marketing aggregators for their booking and schedule management. It was known from the analysis that hotels established 2 decades earlier followed very traditional approach .For Example: Entering the day to day booking activities in register maintained kind of book which was kept in the reception area.

\section{Hotel management IT applications}

Technology mediated environment in service process in hospitality industry have a direct influence on customer satisfaction. (Froehle 2006) E-commerce has enhanced the way of operating business, it has created a great significance to travel and Tourism industry, E-commerce is instrumental in promoting tourism and selling holiday packages to the hospitality enterprises in India, to a large extent, and the phenomenon of E-Commerce practices has been adopted by every enterprises operating in the leisure and hospitality sectors to provide a differentiated services by categorizing their offerings .The present study has been undertaken to analyze the trends prevailing in E-Commerce and single sided ECommerce and examine the barriers and limitations 
underwent by the industry practitioners and issues faced by the service providers (Mitra,2013), Various hotel booking and scheduling software has been adopted and implemented by the hotel and lodging enterprises and there by catering the needs and operational management of the hotels, which made the hotels operating in traditional format to adopt technological changes in terms of computers. For Example: Digital tablets were used by front office staff to schedule the booking of rooms and receive the guest identification documents which can be viewed by the owner or the hotel manager through online and track the day sales reports successfully without his day to daypresence.

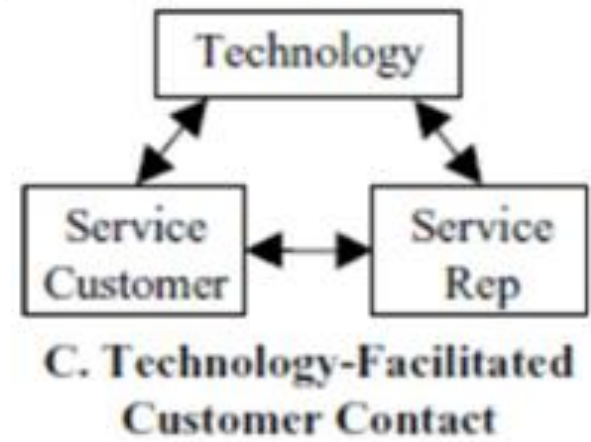

C. M. Froehle, A. V. Roth / Journal of Operations

Management 22 (2004) 1-21

Fig.1. Conceptual archetypes of customer contact in relation to technology.

The service operation concept of this hotel industry can be referred to the above shown model where there is theory development with respect to customer contact and technology mediation, the process of booking the hotel property through online modes by consumer can be referred to the above shown model, Where there is technology-facilitated customer contact where, during the face-to-face service encounter, both the service representative and the customer have access to the same technology. Example. Consumer making the payment through online mode and the customer service representative also uses technology to confirm bookings by using internet technology.

\section{Marketing aggregators and impact on innovation}

Innovations serve to help survive on the market, to improve processes and products and to upgrade business concepts managers must consider the significance of staying competitive by prompt response to customers' demand((Ivkov et.al,2016)

The role of marketing aggregators is of great significance to this industry, Recent new startups like
Oyo rooms, Treebo, Zo rooms, make my trip.com has made its presence into this place and there by collaborating for the booking management and capacity utilization of the properties which was found as innovative to many practitioners and effective inventory management of the hotel rooms.

Many of the hotels in this area who were located far away from the city limits and hotels which had minimum occupancy ratio in a month collaborated with these marketing aggregators for fair occupancy ratio.

\section{Marketing Strategy and role of E-Commerce}

The analysis shows that ecommerce had a great significance on the revenue management and marketing aggregators played an important role in the booking management in recent years.

It was known from the analysis that most of the hotels had a walk in customer arriving into the hotel were customers from different demographic factors and also were tech savvy consumers. Example. The analysis from the research revealed that the guest who checked inn to the 1 star and 2 star hotels used mobile phone applications for processing their booking and also for making payments through various payment applications.

During the commencement of this hospitality enterprises and post commencement period the hotel and lodging enterprise owners were operating their occupancy transactions through commission basis. Example .If a group of family arrived at a railway station the local auto rikshaw drivers or cab drivers approached these people for accommodation needs and they would take these guests to the nearby hotels for which they were paid a commission or incentives by the managers of the hotel, but after the advent of online travel portals the hotel owners and managers were relieved from the hassle of marketing their property as there was professional marketing of their hotels through online. The rise of social networking websites and travel portal websites has changed the service consumption pattern of tourists and the planning of journey. This has given rise to various social networking sites to serve the needs of tourists .Trip Advisor is once such online social travel networking web page playing an important role in changing the way tourists plan their trips. These websites allow users to interact and provide reviews 
on hotels or on local tourist attractions and it is a consumer generated content (Miguéns et al., 2008)

The analysis also revealed that increase in the sales of units and occupancy ratio were gradually improved because of collaboration and franchising with popular brands of hotel chains.

\section{Pricing strategy and tariff}

The concept of discount pricing strategy attained a prominence and it is one aspect of innovation as consumers price consciousness attitude made them to book the rooms through different web portal and attaining discounts on their booking.

\section{Operational management}

Human resources are very important to the hospitality industry, since competency of manager and employees can affect innovations and future of the company in general. This is of a high importance because perceived service quality positively influences customer continuance and loyalty(Ivkov et.al,2016).Unified set of characteristics of Customer service representatives to the technology mediated service environment helps in better operational decision making with respect to staff allocation and training and investment on technology(Froehle 2006)

The major aspects of innovation in the recent in the recent years included the operational changes underwent by restaurants in Udupi, where by computerization and other technological gadgets like digital tablets were used for day to day operational activities of restaurants with respect to order processing of the customers, inventory management in day to day operations of restaurants etc.

\section{Customer relationship management and customer retention}

Hotels and resorts operating under 2 star and 3 star category in this area followed a better system of CRM approach, it was known from the interview to the managers that the task was given to the front office staff to frequently follow their reviews posted in web pages of different hotel booking sites and on time reply to the same was given and feedbacks were analyzed. The managers and front office staff were allocated the task of replying for reviews posted in the travel web pages. There should be extensive research and a better understanding of customer perceptions of service quality in service enterprises for the purpose of consumer satisfaction and retention((Froehle 2006)
Reviews, comments and ratings on a hotel generated through these online forums are deciding factor of other prospective consumers who plan to visit the same destination as the reviews are carried out by proof of photos posted in these web pages, the consumers are refrained from booking those hotels those with negative reviews(Miguéns et al., 2008).Web pages and social media of the hotel enterprises is of great significance to the management of the hotel as they include reviews and images posted by existing consumer sharing their experience of service in the particular hotel has changed consumers perception on booking the hotel services( Mahendru,2015).Hotel industries has realized the significance of the opinions and feedback posted by consumers in the online travel portals like trip advisor and $96 \%$ of the hotel enterprises surveyed were of the opinion that reviews played a vital role on generating business(Mahendru,2015)

\section{Revenue management and ROI (Return on investments)}

Innovational operational aspects and technological development has remarkable significance on the revenue management of hotels and restaurants. It was known from the analysis that present day business and market conditions were volatile in nature both in terms of revenue and overall turnover. The lodging and restaurants operating in this location were transforming itself towards effective revenue management.

Marketing of hotel industry through digital modes is an economical and effective methodology to allocate limited resources in the enterprise and ensure a fair return on investment (Mahendru, 2015)

The practitioners and managers explored new possibilities of increasing the occupancy ratio of rooms and gross operating profit per available room (GOPPAR) which was the key performance indicator where ROI was one of the primary objectives along with efficient service. As investment on a property for establishment of hotels and lodging involved huge liability from the banking and financial institution made the revenue manager explore various possibilities of enhancing the revenue.

Practical implications: The learning from the above factors reveal that how the hotels and restaurants adopted change management successfully. Segment of guests arriving to the hotels for stay and leisure in this 
location include pilgrims and family households and minimum number of corporates, but the focus is on innovational aspects adopted by these enterprises to remain competitive by differentiating their service strategies.

\section{Case Studies}

Innovation and new service development in the hospitality industry with reference to hotels and Restaurants in Udupi city has enabled the hospitality firms especially restaurants to leverage the technology and gain operational efficiency and which has led to optimum utilization of resources of the enterprises. Cafe 7 Bees is one among favorite place for a small gatherings, parties, or just hangout. From its inception it has seen a large growth in its business by serving tasty and amazing snacks with a large varieties where everyone can have something they love. Cafe 7 Bees is a pure veg restaurant maintaining its high standard of quality and services through years. The brand has been in existence from a long time and is renowned for its commitment to authentic \& hygienic food, and good service. Since its inception it used manual methods of order processing for example: Orders for food were placed in a restaurant through a server who was taking orders through a KOT (Kitchen order token) books and the same was submitted to the kitchen and orders were processed. In recent years in order to improve its operational efficiency it adopted technological gadgets and an application named restobyte software which led to a drastic changes in their day to day operations. Some of the special features included following:

\section{POS Integration (Point of sale)}

The digital menu of this restaurant has been integrated with its desktop POS (Point of sale), so that the orders are directly integrated to POS unit. This is designed to give the restaurant all the necessary tools to increase efficiency and speed up service

\section{Existing Menu Presentation}

The restaurant can make it simpler for the guests to navigate through the digital menu and know accurately what they are looking for, by customizing the menu, customizing the menu according to current trends and adding descriptions for each item. Example: If a consumer who do not prefer cheese for a burger may customize his order and at the same time the sever will make a note of this where the same will be displayed in the kitchen terminal and the chef in the kitchen will process the order according to the needs of consumer

\section{Real Time Updates of Menu \& Reports}

Efficient service operations management with reference to a restaurant Management, offering a unique feature to display prompt concise reports and can help the firm to update their menu instantly throughout all the devices. The restaurants unique feature includes the display of a LED (T.V) which includes the menu presented with health benefits in presentable manner. For .Example: The images of fruit juices are presented including health benefits are displayed and similarly many other food items are displayed where by customer dining experiences are delighted and long lasting ambiences are created in the minds of consumers. The restaurant is able to adapt current menu trends and it easily customize the menu and the overall style following the current trends and enhance customer delight and service experience.

\section{Effortless Up sell Upsurges Revenue}

The restaurant can easily use this application to make their order processing of items more appealing to consumers by publicizing them with relevant pictures and latest information through its interactive features as a result the enterprises can upsurge sales and have an amplified revenue

\section{ALL ABOUT PROCESS \\ Waiter Provided With the Tablet}

This innovative application with the use of digital tablet delivers a better guest experience and contributes to higher satisfaction. The POS system helps waiter to take orders quickly with a detailed information about the order and occupied table, leaving no chance for the guest to complain.

\section{Kitchener Provided With Tablet / Desktop / Printer}

The orders are noted down by the customer service representative are displayed in the terminal of kitchen, where the chef can start processing the customized orders. 
Conceptual archetypes of customer contact in relation to technology in service operations

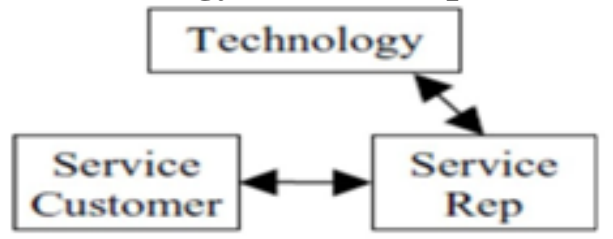

Source: C. M. Froehle, A. V. Roth / Journal of Operations Management 22 (2004) 1-21(Perception of technology mediated customer service)

\section{Interaction in Influencing Customer Satisfaction}

The service operation concept of this restaurant can be referred to the above shown model where there is theory development with respect to customer contact and technology mediation, Customer service can involve technology in a variety of ways, as illustrated in Figure 1 (Froehle\&Roth, 2004), in which the concept of customer contact in relation to technology is context is illustrated through distinct conceptual archetypes, where the archetype is technology assisted customer contact. The service rep employs technology as an aid to improve the face-to-face contact, but the customer does not have access to the technology , To improve processes and to upgrade business technology is gradually replacing human labor in the restaurant industry, (Ivkov et.al,2016) There is increase in application of information and communication technologies to improve efficiency, cost effectiveness and quality of services and customer service representativeness having a direct implication towards consumer perception on service experience ( Froehle \& Roth,2003)

Conclusion of the case: Leverage of technology in business and appropriate adoption in operation will lead to competitive advantage and economical efficiency. The restaurant manager is of the opinion that earlier the restaurant had normal approach of order processing where customer service representatives were many in numbers and each customer service representatives used to take orders which took 15 minutes to process orders which involved consumption of time and the order processing of other tables were delayed which led to queuing of consumers ultimately leading to constraint of service operations. As a result of which the restaurants operations were revitalized through information and technological application which is a significant innovation. The ultimate conclusion is with reference to operational management of hotel can be that the restaurant has leveraged technology and optimum utilization of technology in day to day operation which has led to reduction in overheads with reference to labor investments and ultimate operational efficiency and increasing customer service delight and experience.

\section{Comparison study of a restaurant which deals with multi cuisine menu offerings}

Restaurant B is a popular for Chinese and north Indian cuisines in Manipal which has 15 tables where approximately 50 members can accommodate at a time. The segment of consumers of this restaurant includes family members, food lovers, professionals who spend their time here for celebrations and normal dining and lunch. The format in which this restaurant operates is traditional in nature. Example: When a consumer walks in with his family an order will be placed through servers by looking at menu card and server takes the order through KOT and it is given in the kitchen to the chef for order processing, which will approximately take 15 minutes for order to be processed.

The fact to be noted is though the restaurant has a fair number of customer walk in and excellent review about the service offerings but it lacks innovation in its operations and lack of strategic planning at operational level as there is no proper leverage of technology.

When an in depth interview was held with the manager of the restaurant it was known that technological adoption in the day to day operation is a constraint and a barrier to the firm. It was known from the interview that the management team of this restaurant $\mathrm{B}$ were of the opinion that adoption of tablets for order processing amongst customer service representatives was an issue due to technical complexity and literacy issue played a prominent aspect. The analysis also revealed that there was lack of adoption from tactical level and operational level and the perception of the members at operational level about the new system was negative which involved complacency in their mind which is a major barrier and hindrance for new service development. 
International Journal of Trend in Scientific Research and Development (IJTSRD) ISSN: 2456-6470

\section{Comparison table between traditional and modern approach of Hospitality}

\begin{tabular}{|c|c|c|}
\hline Basis & Restaurant A & Restaurant B \\
\hline $\begin{array}{c}\text { Service } \\
\text { Operations }\end{array}$ & Innovative and enterprising & Traditional and lack of new features \\
\hline Cost cutting & $\begin{array}{l}\text { Cost - cutting and cost efficiency from } \\
\text { the operational aspect point }\end{array}$ & $\begin{array}{c}\text { Overheads at every part of operations } \\
\text { requires labour investment }\end{array}$ \\
\hline Investment & $\begin{array}{c}\text { Fixed investment and certain } \\
\text { maintenance charges }\end{array}$ & Budget constraint and other technical issues \\
\hline $\begin{array}{l}\text { Customer } \\
\text { loyalty }\end{array}$ & $\begin{array}{l}\text { Customer loyalty and increase in } \\
\text { delight of customer service experience }\end{array}$ & $\begin{array}{c}\text { Customer loyalty in terms delicacies and cuisines } \\
\text { and service experience is lacking amongst } \\
\text { consumers }\end{array}$ \\
\hline $\begin{array}{l}\text { competitive } \\
\text { advantage }\end{array}$ & $\begin{array}{l}\text { Low cost of operations and speedy } \\
\text { service }\end{array}$ & $\begin{array}{c}\text { Lack competitive advantage and there is a delay in } \\
\text { order processing of orders }\end{array}$ \\
\hline
\end{tabular}

\section{DATA ANALYSIS AND INTERPRETATION}

As per the research Udupi district comprises around 50 -60 lodging out of which around 10 are working under star category. The questionnaires were distributed amongst the managers and also in depth interviews were taken.

The sample included 60 hotels of all categories non classified and 2 and 3 stars, where in each hotel the manager was requested to complete the survey. The questionnaire was written in English.

Table 1: Cross tabulation between category of hotels and duration of these hotels in the industry

\begin{tabular}{|c|c|c|c|c|c|c|}
\hline \multicolumn{7}{|c|}{ Count } \\
\hline & & \multicolumn{4}{|c|}{ Category of hotels } & \multirow[b]{2}{*}{ Total } \\
\hline & & Non Classified & $1 \mathrm{Star}$ & 2 star & 3 star & \\
\hline \multirow{4}{*}{ Years in hospitality Business } & Less than 5 years & $\mathrm{ch} 2 \mathrm{2}$ & 25 & 2 & 1 & 30 \\
\hline & 5-10 Years & 2 & 7 & 6 & 2 & 21 \\
\hline & 10-20 Years 10 & OnIe 2 & 0 & 0 & 2 & 4 \\
\hline & More than 20 years & 6 & 2 & 1 & 0 & 5 \\
\hline Total & O IGQN. $2 \mathrm{~A}$ & $6.6 / 12$ & 34 & 9 & 5 & 60 \\
\hline
\end{tabular}

The survey was conducted to analyze the duration of years in the hospitality sector, the analysis revealed that $3 \%$ of the respondents operated in 1 star format and which were established 5 years ago and $3 \%$ of the hotels were non classified in nature which were established around 5 to 10 years ago, and around $10 \%$ of the hotel enterprises were non classified in nature operating traditional format of booking and management which were established around 20 years which gives a micro view on their establishment and category of the hotels ,and around after technological adoption in business practices around $41 \%$ were the hotels newly established under 1 star category within a span of 5 years in this location.

Table 2: Cross tabulation between duration of the hospitality enterprises and application of information technology in their business

\begin{tabular}{|c|c|c|c|c|}
\hline \multicolumn{2}{|c|}{} & \multicolumn{3}{|c|}{ Use of IT } \\
\cline { 2 - 5 } & Yess than 5 years & 17 & 13 & 30 \\
\hline \multirow{4}{*}{ Years in hospitality Business } & $5-10$ Years & 14 & 7 & 21 \\
\cline { 2 - 5 } & $10-20$ Years & 2 & 2 & 4 \\
\cline { 2 - 5 } & More than 20 years & 3 & 2 & 5 \\
\hline & Total & 36 & 21 & 60 \\
\hline
\end{tabular}


The analysis revealed that those hotel and lodging enterprises established less than 5 years among which $2 \%$ of the respondent firms were exclusively employing computers for the day to day room booking and for the scheduling of their rooms and inventory and 5\% among the respondents followed the ancient approach of operations and booking management, neither there was any transformation of any computerization in these firms.

Table3: Cross tabulation between duration of the hotels in the industry and mode of booking the rooms.

\begin{tabular}{|c|c|c|c|c|c|}
\hline \multicolumn{2}{|c|}{} & \multicolumn{3}{c|}{ Mode of booking } & \multirow{2}{*}{ Total } \\
\cline { 3 - 7 } & Walk in & Booking websites & Phone call & \\
\hline \multirow{3}{*}{ Years in hospitality Business } & Less than 5 years & 7 & 18 & 5 & 30 \\
\cline { 2 - 6 } & $5-10$ Years & 3 & 16 & 2 & 21 \\
\cline { 2 - 6 } & $10-20$ Years & 2 & 1 & 1 & 4 \\
\cline { 2 - 6 } & More than 20 years & 3 & 2 & 0 & 5 \\
\hline
\end{tabular}

The analysis revealed that $12 \%$ of the hotels and lodging firms in this area had operated their booking of rooms through customer walk in that with respect to the hotels established within last 5 years and $30 \%$ of the enterprises established 5 years ago had excessive reliability on online booking operations and online travel portals for their scheduling of rooms and $26 \%$ of the firms established around last 10 years also relied on online travel portals.

Table 4: Cross tabulation between revenue management and duration of the business

\begin{tabular}{|c|c|c|c|c|c|c|c|}
\hline & \multicolumn{5}{|c|}{ Revenue Management } & \multirow[b]{2}{*}{ Total } \\
\hline & & $\begin{array}{c}\text { Strongly } \\
\text { Agree }\end{array}$ & Agree & Average & Disagree & $\begin{array}{l}\text { Strongly } \\
\text { Disagree }\end{array}$ & \\
\hline \multirow{4}{*}{$\begin{array}{c}\text { Years in hospitality } \\
\text { Business }\end{array}$} & Less than 5 years & 16 & 10 & 4 & 0 & 0 & 30 \\
\hline & 5-10 Years & Re5az & 8 & 7 & 0 & 1 & 21 \\
\hline & 10-20 Years & 0 & 2 & 2 & 0 & 0 & 4 \\
\hline & More than 20 years & $D e 2$ elO & $0 \pi 1 \mathrm{el}$ & 1 & 1 & 0 & 5 \\
\hline \multicolumn{2}{|c|}{ Total } & 23 & 21 & 14 & -1 & 1 & 60 \\
\hline
\end{tabular}

The analysis revealed that around $26 \%$ of the respondent firms which were established in the span of less than 5 years were of the opinion that collaboration with the booking websites had improved their revenue efficiency and these firms were of the opinion that booking websites were of great significance to these firms because the marketing and sales operations were performed by these intermediaries.

Table 5: Cross tabulation representing relationship between online travel portals and duration of the firms

\begin{tabular}{|c|c|c|c|c|c|c|}
\hline \multicolumn{7}{|c|}{ Count } \\
\hline & & \multicolumn{4}{|c|}{ Collaboration } & \multirow[b]{2}{*}{ Total } \\
\hline & & Goibibo & $\begin{array}{l}\text { Make my } \\
\text { trip }\end{array}$ & Booking.com & $\begin{array}{l}\text { Trip } \\
\text { Advisor }\end{array}$ & \\
\hline \multirow{4}{*}{$\begin{array}{c}\text { Years in hospitality } \\
\text { Business }\end{array}$} & Less than 5 years & 11 & 10 & 5 & 4 & 30 \\
\hline & 5-10 Years & 6 & 9 & 3 & 3 & 21 \\
\hline & 10-20 Years & 0 & 1 & 2 & 1 & 4 \\
\hline & More than 20 years & 1 & 2 & 1 & 1 & 5 \\
\hline \multicolumn{2}{|c|}{ Total } & 18 & 22 & 11 & 9 & 60 \\
\hline
\end{tabular}

The managers were interviewed with aspect of the most preferred online travel portal which leveraged the revenue management of the firms, it was known from the analysis that those firms established in recent years around $18 \%$ of the firms had marketing collaboration with goibibo, a popular online travel portal which was most preferred among the managers for the scheduling and marketing of rooms and effective revenue 
management and around 6\% of the firms established in the recent years had tie up with online travel portal tripadvisor and the remaining firms never had any tie ups with trip advisor it was employed as a medium to analyze their feedback posted by consumers.

Table6: Cross tabulation representing duration of the hotels in the hotel industry sector and valuation of the hotel property

\begin{tabular}{|c|c|c|c|c|c|}
\hline \multicolumn{2}{|c|}{} & \multicolumn{3}{c|}{ Valuation of hotel } \\
\cline { 3 - 6 } & 1 Crores & $1-5$ Crores & More than 10 Crores & Total \\
\hline \multirow{3}{*}{ Years in hospitality Business } & Less than 5 years & 6 & 21 & 3 & 30 \\
\cline { 2 - 6 } & $5-10$ Years & 5 & 11 & 5 & 21 \\
\cline { 2 - 6 } & $10-20$ Years & 0 & 2 & 2 & 4 \\
\cline { 2 - 6 } & More than 20 years & 0 & 3 & 2 & 5 \\
\hline
\end{tabular}

The above shown cross tabulation presents an analysis of duration of presence of these firms in hospitality industry and market valuation of these firms and their properties.3\% of the respondent firms established around 20 years earlier had a market valuation of more than 10 crore and around $18 \%$ of the respondent firms had a valuation 1 to 5 crore, which presented a analysis on the valuation of these firms and an idea on commercial aspects and investment clarity in these location with respect to hotel industry.

Table 7: Cross tabulation representing duration of the hotels in the hotel industry sector and number of employees presently employed in these enterprises

\begin{tabular}{|c|c|c|c|c|c|}
\hline \multicolumn{6}{|c|}{ Years in hospitality Business * Number of employees Cross tabulation } \\
\hline \multicolumn{6}{|c|}{ Count } \\
\hline & & \multicolumn{3}{|c|}{ Number of employees } & \multirow{2}{*}{ Total } \\
\hline & & $5-10$ & $10-30$ & More than 50 & \\
\hline \multirow{4}{*}{ Years in hospitality Business } & Less than 5 years & 15 & 11 & 4 & 30 \\
\hline & 5-10 Years & 6 & 13 & 2 & 21 \\
\hline & $10-20$ Years & 1 & $1 \odot$ & +8 & 4 \\
\hline & More than 20 years & 42 & 1 & 2 & 5 \\
\hline Total & 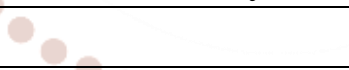 & 24 & 26 & 10 & 60 \\
\hline
\end{tabular}

From the above analysis it is known that hotels established around less than 5 years span of time among which $25 \%$ of the hotels had more than 5 employees exclusively to manage the operations of scheduling the rooms and offering innovative service amenities and around 66\% of these firms had more than 50 employees which was established around last 5 years span of time out of which some of them were operating in 4 and 3 star category basis. The number of employees and duration of the time of business gives a clear understanding on new service development strategies adopted by these firms with employees base exceeding 15 or more than 15 .

Table 8: Cross tabulation between Duration of the firms in the hospitality sector and adoption of technology

\begin{tabular}{|c|c|c|c|c|}
\hline & \multicolumn{2}{|c|}{ Adoption of technology } & \multirow{2}{*}{ Total } \\
\hline & & Yes & No & \\
\hline \multirow{4}{*}{ Years in hospitality Business } & Less than 5 years & 18 & 12 & 30 \\
\hline & 5-10 Years & 17 & 4 & 21 \\
\hline & 10-20 Years & 4 & 0 & 4 \\
\hline & More than 20 years & 5 & 0 & 5 \\
\hline \multicolumn{2}{|l|}{ Total } & 44 & 16 & 60 \\
\hline
\end{tabular}


International Journal of Trend in Scientific Research and Development (IJTSRD) ISSN: 2456-6470

Table 9: Cross tabulation between duration and mode of hurdle in adoption of technology

\begin{tabular}{|c|c|c|c|c|c|c|}
\hline \multicolumn{7}{|c|}{ Count } \\
\hline & & \multicolumn{4}{|c|}{ Mode of hurdle } & \multirow[b]{2}{*}{ Total } \\
\hline & & Education & $\begin{array}{l}\text { Technical } \\
\text { Complexity }\end{array}$ & $\begin{array}{c}\text { Low Level } \\
\text { Management } \\
\text { adoption }\end{array}$ & $\begin{array}{c}\text { Time } \\
\text { Consumption } \\
\text { and errors }\end{array}$ & \\
\hline \multirow{4}{*}{$\begin{array}{l}\text { Years in } \\
\text { hospitality } \\
\text { Business }\end{array}$} & Less than 5 years & 14 & 12 & 4 & 0 & 30 \\
\hline & 5-10 Years & 10 & 5 & 5 & 1 & 21 \\
\hline & 10-20 Years & 1 & 1 & 1 & 1 & 4 \\
\hline & More than 20 years & 2 & 2 & 0 & 1 & 5 \\
\hline \multicolumn{2}{|r|}{ Total } & 27 & 20 & 10 & 3 & 60 \\
\hline
\end{tabular}

The analysis revealed that $23 \%$ of the firms established around 5 years ago had education as a major barrier to adopt technological changes in day to day practices and $20 \%$ of the firms had technical complexity as a major barrier for adoption of technological changes in day to day operations amongst the firms established around 5 years ago, remaining $33 \%$ of the firms which were established around 20 years ago had education as a major barrier to adopt technological changes.

Table 10: Cross tabulation between duration and present day challenges

\begin{tabular}{|c|c|c|c|c|c|}
\hline & \multicolumn{3}{|c|}{ Present day } & \multirow[b]{2}{*}{ Total } \\
\hline & & $\begin{array}{l}\text { Changes in } \\
\text { tastes and } \\
\text { preferences }\end{array}$ & $\begin{array}{l}\text { Competitors } \\
\text { innovative } \\
\text { service } \\
\text { strategies }\end{array}$ & $\begin{array}{l}\text { Lack of } \\
\text { skilled and } \\
\text { efficient } \\
\text { employees }\end{array}$ & \\
\hline \multirow{4}{*}{$\begin{array}{c}\text { Years in hospitality } \\
\text { Business }\end{array}$} & Less than 5 years & 13 & $=14$ & 3 & 30 \\
\hline & 5-10 Years & 11 & 6 & 4 & 21 \\
\hline & 10-20 Years & ear 2 han & 8 & 0 & 4 \\
\hline & More than 20 years & 1 & 3 & 1 & 5 \\
\hline & a & EIO 27 IIE & 25 & 8 & 60 \\
\hline
\end{tabular}

Around $23 \%$ of the firms established 5 years ago were of the opinion that competitors service strategies was an important and prime challenge which included competitive firms in hotel enterprises offering new amenities and discount price offers for booking rooms through online mode, and around $22 \%$ of the firm established around 5 years back were of the opinion that changes in tastes and preferences of consumers was a great present day challenge to customize the service strategy according to the needs of consumers and around $5 \%$ of the firms established around 20 years were of the opinion that competitive aspects is one among the challenges to operate in present day business.

Table 11: Cross tabulation between duration and source of innovation

\begin{tabular}{|c|c|c|c|c|c|}
\hline & \multicolumn{3}{|c|}{ Source of Innovation } & \multirow[b]{2}{*}{ Total } \\
\hline & & Customer & $\begin{array}{l}\text { Competitive } \\
\text { practices }\end{array}$ & $\begin{array}{l}\text { Changes in } \\
\text { demographics } \\
\text { of consumers }\end{array}$ & \\
\hline \multirow{4}{*}{$\begin{array}{c}\text { Years in hospitality } \\
\text { Business }\end{array}$} & Less than 5 years & 12 & 11 & 7 & 30 \\
\hline & 5-10 Years & 9 & 7 & 5 & 21 \\
\hline & 10-20 Years & 2 & 1 & 1 & 4 \\
\hline & More than 20 years & 3 & 1 & 1 & 5 \\
\hline \multicolumn{2}{|c|}{ Total } & 26 & 20 & 14 & 60 \\
\hline
\end{tabular}

The analysis stated that around $20 \%$ of the firms established around 5 years ago were of the opinion that consumer and consumer preference is one of the major source of innovation for their new service development 
and formulating new service strategy and around $18 \%$ of the firms operating less than 5 years ago were of the opinion that competitive practices adopted by service firms and other competitors served as a source of innovation.

Table 12: Descriptive Statistics representing factors of innovation with their ranks

\begin{tabular}{|c|c|c|c|}
\hline \multicolumn{3}{|c|}{ Descriptive Statistics } \\
\hline Important factor & $\mathrm{N}$ & Mean & Std. Deviation \\
\hline Online booking and franchising with travel aggregators & 60 & 3.4667 & 1.21386 \\
\hline Changes in features of services currently offered & 60 & 3.1667 & 1.57487 \\
\hline Service offerings & 60 & 2.8833 & 1.05913 \\
\hline Discounts and low cost pricing strategies & 60 & 3.0333 & 1.48400 \\
\hline Ambience of the property & 60 & 2.4667 & 1.41980 \\
\hline Valid N ( List wise) & 60 & & \\
\hline
\end{tabular}

A. Statistical Interpretation:

Considering all the factors based on mean value factor one having highest with the mean score of 3.4667, followed by factor 2 with the mean score of 3.1667, followed by factor 4 mean score 3.033, followed by factor 3 with the mean score 2.8833 factor 5 score least mean score considering all the five factors with the mean score of 2.4667 .

B. Subjective Interpretation:

The analysis revealed that most important factor of innovation included the online booking and revenue management through franchising modes of business. For example franchising the hotel and lodging firms with chain of hotel companies like tree Bo and Oyo rooms, which had high scores $(\mathrm{M}=3.4667, \mathrm{SD}=1.21386)$ than ambience of the property which had low scores $(\mathrm{M}=2.4667, \mathrm{SD}=1.41980)$ and there was a minimum difference between 2 factors of innovation namely Discounts and low cost pricing strategies and features of services with respective score $(\mathrm{M}=3.0333, \mathrm{SD}=1.48400)$ and $(\mathrm{M}=3.1667, \mathrm{SD}=1.57487)$.

13. Kruskal-Wallis test

Hypothesi here is no significant difference among mean rank of Mode of Booking with regard to Growth in Revenue management and efficiency of the hospitality industry

\begin{tabular}{|c|c|c|c|}
\hline \multicolumn{4}{|c|}{ Ranks } \\
\hline Particulars & Mode of booking & N & Mean Rank \\
\hline \multirow{3}{*}{ Revenue Management } & Walk in & 15 & 42.67 \\
\cline { 2 - 4 } & Booking websites & 37 & 25.05 \\
\cline { 2 - 4 } & Phone call & 8 & 32.88 \\
\cline { 2 - 5 } & Total & 60 & \\
\hline
\end{tabular}

\begin{tabular}{|c|c|}
\hline \multicolumn{2}{|c|}{ Test Statistics } \\
\hline & Revenue Management \\
\hline Chi-Square & 12.412 \\
\hline Df & 2 \\
\hline Asymp. Sig. & $0.002 * *$ \\
\hline
\end{tabular}

Interpretation: From Kruskal-Wallis test (Chi-Square Test value 12.412) There is high significant difference among mean rank of Mode of Booking with regard to Growth in Revenue management and efficiency of the hospitality industry at $1 \%$ level of significance as the $\mathrm{p}$ values are lesser than 0.01 So, we are accepting alternative hypothesis at $1 \%$ level of significance

14. Friedman Test

Hypothesis: There is no significant difference among mean rank towards Factors of innovation in hospitality industry 
International Journal of Trend in Scientific Research and Development (IJTSRD) ISSN: 2456-6470

\begin{tabular}{|c|c|c|c|c|}
\hline Particulars & Mean Rank & Rank & Chi-Square Value & P value \\
\hline Ambience & 3.53 & 1 & & \\
\hline Computerization & 3.17 & 2 & & \multirow{2}{*}{15.679} \\
Service offerings & 2.86 & 4 & \multirow{2}{*}{$<0.003^{* *}$} \\
\hline Discounts and low cost pricing strategies & 3.00 & 3 & & \\
\hline Changes in menu & 2.44 & 5 & & \\
\hline
\end{tabular}

Interpretation:

From Friedman's Test it can be observed that among preference on most important Factors of innovation in hospitality industry. Factor 1 - highest preference factor with mean rank 3.53, followed by factor with mean rank 3.17. Next preferred factor, factor 4 with a mean rank of 3.00, followed by factor 3 with a mean rank of 2.86 and the least preferred on Factor 5 with mean rank of 2.44,there is high significant difference in the preference on Factors of innovation in hospitality industry is tested with Friedman test. Since the value of $p(p=0.000<0.01)$ there is significant difference at $1 \%$ level of significance in the ranking for preference on Factors of innovation in hospitality industry.

15. Mann Whitney- U test

Null Hypothesis: There is no significant difference between mean rank of usage of IT with regard to Various factors of innovation in the hospitality sector with reference to hotel industry.

\begin{tabular}{|c|c|c|c|l|}
\hline \multirow{2}{*}{ Factors of innovation in hospitality industry } & \multicolumn{2}{|l|}{ Mean Rank of Use of IT } & \multirow{2}{*}{ Z value } & \multirow{2}{*}{ P value } \\
\cline { 2 - 5 } & Yes & No & & \\
\hline Ambience & 28.81 & 29.33 & -0.121 & 0.904 \\
\hline Computerization & 25.22 & 35.48 & -2.312 & $0.021^{*}$ \\
\hline Service offerings ternatioricing strategies & 32.92 & 22.29 & -2.426 & $0.015^{*}$ \\
\hline Discounts and low cost pricing & 32.57 & 22.88 & -2.172 & $0.030^{*}$ \\
\hline Changes in menu & 26.06 & 34.05 & -0.819 & 0.069 \\
\hline
\end{tabular}

\section{Interpretation:}

\section{From Mann-Whitney $U$ test it can be observed} that there is significant difference in the the mean preference for Computerization, Service offerings and Discounts \& low cost pricing strategies between User of IT and Non- user of IT respondents at 5\% level of significance, since $p$ value is less than 0.05 . So we are accepting alternative Hypothesis at $5 \%$ Level.

2.From Mann-Whitney $U$ test it can be observed that there is no significant difference in the the mean preference for Ambience and Changes in menu between User of IT and Non-user of IT respondents at $5 \%$ level of significance since $p$ value is more than 0.05 . So we are accepting Null Hypothesis.

\section{RECOMMENDATION:}

Human resources are very important to the hospitality industry, since competency of manager and employees can affect innovations and future of the company in general. This is of a high importance because perceived service quality positively influences customer continuance and loyalty (Ivkov et.al, 2016)
The operational efficiency of restaurant $B$ can be improved provided the perception of the technicalities and complexity of using digital tablets for order processing can be used by the customer service representative. The investment in the digital order processing applications will cost around 50-70 K, including hardware infrastructure and installation of LED menu and presentations in the restaurant will enhance consumer service experience and also the process of orders can also be projected through documentary video which will enhance consumer service experience ultimately resulting in new service strategy from the firm.

\section{CONCLUSIONS}

From these results, it appears that the strategic operations choices where service firms make regarding IT, the use of human resource for NSD, and NSD process design significantly influence their ability to develop new services quickly and effectively. IT choices appear to play a significant role in improving both the speed of the NSD process and the effectiveness of the firm's NSD efforts. Thus, investments in process-enabling information 
technologies can yield multiple benefits increasing the generation of new ideas, accelerating the development of new services based on those ideas, and generally supporting the firm's goal of rapidly bringing new offerings to market. So, NSD process improvement efforts, based on the implementation and introduction of new IT tools, appears to be justified as long as proper organizational preparations have been made. This finding suggests that those service firms with formal and reproducible processes for developing new and enhanced services are more likely to outperform competitors by taking advantage of "first mover" benefits or by quickly imitating leading- edge competitors

\section{REFERENCES}

Books, Publications, Journals, Articles and Websites:

\section{Books:}

$>$ Metters, R., \& Metters, R. (2006). Successful service operations management. Mason, $\mathrm{OH}$ : South- Western

\section{Publication, Journals, Articles:}

1. Abhijit Mitra (2013), "E-Commerce in India- A Review", International journal of Marketing, Financial Services \& Management Research, ISSN 2277- 3622, Vol.2, No. 2, February(2013)

2. Archana Bhatia (2013), SWOT Analysis of Indian tourism Industry", International Journal of application or Innovation in Engineering \& Management (IJAIEM), Volume 2, Issue 12

3. Bilgihan, Anil., Nejad., Mohammad, (2015) "Innovation in hospitality and tourism industries", Journal of Hospitality and Tourism Technology, Vol. 6 Issue: 3

4. Froehle, C. (2006). Service Personnel, Technology, and Their Interaction in Influencing Customer Satisfaction*. Decision Sciences, 37(1), pp.5-38.

5. Froehle, C. Roth, A. (2004). New measurement scales for evaluating perceptions of the technology- mediated customer service experience. Journal of Operations Management, 22(1), pp.1-21.

6. Froehle, C., Roth, A., Chase, R. and Voss, C. (2000). Antecedents of New Service Development Effectiveness. Journal of Service Research, 3(1), pp.3-17.
7. Mahendru., Aarti Dr(2015)Indian Hotel Industry: Transformation Through Digital Marketing, International Journal Of Business Management ISSN NO. 2349-3402 VOL. 2(1)

8. Mavale, S., Rautela, S (2016) Incremental Innovation for Sustainable Growth in Restaurant Businesses: Global Practices for the Growth of Local Business, Vol. 4, Annual Research Journal of SCMS, Pune

9. Miguéns J., Baggio. R., Costa, C. (2008) Social media and Tourism Destinations: Trip Advisor Case study, IASK ATR2008 (Advances in Tourism Research 2008), Aveiro, Portugal, May. 26-28

10. Parasuraman, A., Zeithaml, V. and Berry, L. (1985). A Conceptual Model of Service Quality and Its Implications for Future Research. Journal of Marketing, 49(4), p.41.

11. Rajasekaran. R., Sudarsan, C. (2018). The Impact of E-Commerce on Indian Tourism Industry - The Opportunities and Challenges to E-Tour operators

12. Sanjeev, G., \& Bandyopadhyay, R. (2016). Innovations in the Indian hospitality industry: an overview. Worldwide Hospitality And Tourism Themes, 8(4), 408-415.

13. Sen, K. and Kaushik, T. (2016), "Recent innovative measures across different functions in the Indian hospitality industry: a case of accor hotels", Worldwide Hospitality and Tourism Themes, Vol. 8 No. 5.

14. Siakalli, M. Masouras., A. Papademetriou.,C. (2017) Foundations E-marketing in Hospitality Industry, IJMBS Vol. 7, Issue 1

\section{Websites:}

1. https://www.ibef.org/industry/indian-tourism-andhospitality-industry-analysis-presentati.

2. http://www.businessworld.in/article/HospitalityIndustry-In-India-A-Big-Contributor-ToEconomy-s- Growth-/16-05-2017-118291/

3. https://www.hospitalityupgrade.com/_magazine/ MagazineArticles/Hotel\%20Marketing\%20and\%2 0Revnue\%20Management\%20Are\%20Not\%20Su bstitutes\%20for\%20Innovation.asp 